\title{
Responses of Soil Enzyme Activity and Microbial Community Compositions to Nitrogen Addition in Bulk and Microaggregate Soil in the Temperate Steppe of Inner Mongolia ${ }^{1}$
}

\author{
Yao Shi ${ }^{a}$, Lianxi Sheng ${ }^{a}$, Zhongqiang Wang ${ }^{a, b}, *$, Xinyu Zhang ${ }^{c, * *}$, Nianpeng He ${ }^{c}$, and Qiang Yu ${ }^{d}$ \\ ${ }^{a}$ State Environmental Protection Key Laboratory of Wetland Ecology and Vegetation Restoration, \\ Northeast Normal University, Changchun 130024, China \\ ${ }^{b}$ School of Geographical Science, Northeast Normal University, Changchun 130024, China \\ ${ }^{c}$ Key Laboratory of Ecosystem Network Observation and Modeling, Institute of Geographic Sciences and Natural Resources \\ Research, Chinese Academy of Sciences, Beijing 100101, China \\ ${ }^{d}$ Institute of Applied Ecology, Chinese Academy of Sciences, Shenyang 110016, China \\ *e-mail:wangzq027@nenu.edu.cn \\ **e-mail: zhangxy@igsnrr.ac.cn \\ Received February 3, 2015
}

\begin{abstract}
In order to explore the responses of soil enzyme activities and microbial community compositions to long-term nitrogen $(\mathrm{N})$ addition in both bulk soil and microaggregate of chestnut soil, we conducted a 7 -year urea addition experiment with $\mathrm{N}$ treatments at 6 levels $\left(0,56,112,224,392\right.$ and $\left.560 \mathrm{~kg} \mathrm{~N} \mathrm{ha}^{-1} \mathrm{yr}^{-1}\right)$ in a temperate steppe of Inner Mongolia in China. Soil properties and the activities of four enzymes involved in carbon $(\mathrm{C})$, nitrogen $(\mathrm{N})$ and phosphorus $(\mathrm{P})$ cycling were measured in both bulk soil and microaggregate, and phospholipid fatty acids (PLFAs) were measured in bulk soil. The results indicated that: 1) in bulk soil, $\mathrm{N}$ addition significantly decreased $\beta$-1,4-glucosidase (BG) and leucine aminopeptidase (LAP) activities at the treatment amounts of 224, 392 and $560 \mathrm{~kg} \mathrm{~N} \mathrm{ha}^{-1} \mathrm{yr}^{-1}$, and obviously suppressed $\beta-1,4-\mathrm{N}$-acetylglucosaminidase (NAG) activity at the treatment amount of $560 \mathrm{~kg} \mathrm{~N} \mathrm{ha}^{-1} \mathrm{yr}^{-1}$. $\mathrm{N}$ addition enhanced total PLFAs (totPLFAs) and bacterial PLFAs (bacPLFAs) at the treatment amounts of 392 and $560 \mathrm{~kg} \mathrm{~N} \mathrm{ha}^{-1} \mathrm{yr}^{-1}$, respectively, but fungal PLFAs showed no response to $\mathrm{N}$ addition. The activities of BG, NAG and LAP were positively correlated with soil $\mathrm{pH}$, but negatively correlated with the concentration of $\mathrm{NH}_{4}^{+}-\mathrm{N} ; 2$ ) in microaggregate $(53-250 \mu \mathrm{m})$, the activities of BG, NAG and AP showed no response to increased addition of N, but the significantly decreased LAP activity was observed at the treatment amount of $392 \mathrm{~kg} \mathrm{~N} \mathrm{ha}^{-1} \mathrm{yr}^{-1}$. These results suggested that enzyme activities were more sensitive to $\mathrm{N}$ addition than PLFA biomarkers in soil, and LAP activity in microaggregate may be a good indicator for evaluating $\mathrm{N}$ cycle response to long-term $\mathrm{N}$ addition.
\end{abstract}

Keywords: soil, microaggregate, enzyme activity, PLFA, long-term $\mathrm{N}$ addition, temperate steppe

DOI: $10.1134 /$ S1064229316100124

\section{INTRODUCTION}

Increasing addition of nitrogen $(\mathrm{N})$ has been recognized as an important factor for the functions of terrestrial ecosystem under global change scenarios [39]. Anthropogenic $\mathrm{N}$ enrichment can reveal dramatic impact on the alteration of soil enzyme activities and microbial compositions in $\mathrm{N}$-limited systems [68]. The change of $\mathrm{N}$ availability in soil may increase carbon (C) input through enhancing plant biomass, microbial access to nutrients and soil organic dynamics [25, 33, 43]. As soil $C$ input often affects $C$-limited saprotrophic soil microorganisms, $\mathrm{N}$ availability will be a driving fac-

\footnotetext{
${ }^{1}$ The article is published in the original.
}

tor for controlling the soil microbial decay rate and primary production by affecting soil enzyme activities and microbial community compositions through altered concentrations of soil organic carbon [17].

Grasslands with the soil containing $30 \%$ of carbon pool all over the world play a vital role in maintaining the ecosystem functions such as global carbon cycle and biodiversity [32]. The semiarid temperate steppe in northern China is an important part of Eurasian grassland biome, and has undergone dramatic changes in land type, anthropogenic $\mathrm{N}$ input and climate [41]. The Inner Mongolia grassland, a temperate semi-arid grassland, is sensitive to $\mathrm{N}$ input and atmospheric $\mathrm{N}$ deposition rate has reached at $100-200 \mathrm{~kg} \mathrm{ha}^{-1} \mathrm{yr}^{-1}$ in 
this area [42]. In this temperate semi-arid ecosystem, $\mathrm{N}$ availability is suggested to be a vital driving factor affecting soil enzymes and microbes $[60,70]$.

Studies in temperate steppe focus on the response of plant biomass and soil $\mathrm{C}$ storage to $\mathrm{N}$ addition have indicated the positive influences on aboveground biomass and soil C storage [40, 49, 66, 67]. A three-years of $\mathrm{N}$ addition experiment suggested that $\mathrm{N}$ addition increased root and shoot biomass by 37 and 23\%, respectively, without significant impact on decomposition, causing the increase in soil $\mathrm{C}$ by approximately $15 \%$ [80]. Other researches related to the response of plant community structure to $\mathrm{N}$ addition have suggested the negative influences on plant community and richness, possibly due to the acidifying effect of nitrogen increase $[59,69,75]$. Since soil enzyme activity and microbial community compositions influencing nutrient transformation between soil and plants, the studies on their responses to nitrogen input can be particularly important in understanding the underlying mechanisms of nutrient cycles.

However, nitrogen-based increase in biomass may not translate into the enhancement of soil $\mathrm{C}$ availability $[8,58]$. As soil $\mathrm{P}$ and moisture would influence the shifting of soil $\mathrm{C}$ in plant litter decomposition through increase N-P ratios in organisms or soil moisture by limiting the diffusion of substrates and enzymes, what's more, they will be also altered when $\mathrm{N}$ added $[26,76]$. $\mathrm{N}$ enrichment can also have negative effect on soil microbial growth by changing carbon, water or phosphorus [31, 53]. Previous studies have suggested that excessive $\mathrm{N}$ can inhibit the secretion of ligninase by white rot fungi, thus leading to an accumulation of lignin in soil [65]. Increased lignin will hinder more soil microbes to access cellulose in plant tissues for acquiring carbon or energy through binding or physically blocking, thereby leading to the insufficiency of available $\mathrm{C}$ for soil microbes [44]. The mechanisms of $\mathrm{N}$ addition affecting soil enzymes and microbes have been proposed previously [18]. On the one hand, $\mathrm{N}$ addition can directly inhibit microbial growth through decreasing soil $\mathrm{pH}$, and causing the leaching of magnesium and calcium, and aluminum toxicity [22]. On the other hand, $\mathrm{N}$ addition can also have indirectly effect on soil microbes through altering the availability of carbon.

Soil enzymes (BG, NAG, LAP, AP) are known as sensitive indicators in the decomposition of soil organic matters $[1,3]$. The activity of BG can serve as C acquisition investment and decomposition [28, 61]. NAG and LAP can be secreted by microbes to hydrolyze chitin $[6,24]$ and to break $\mathrm{N}$-terminal amino acid of the polypeptide into leucine, respectively [2, 13]. Besides the degradation of carbon-sources, microbes can also produce phosphatases (AP) to provide the nutrients for growth and enzyme synthesis $[2,54]$. The effect of $\mathrm{N}$ input on enzyme activity in bulk soil is be universally known, but the responses of soil enzyme activity to nitrogen addition in microaggregate need to be further explored.
Soil aggregates, with more intra-aggregate pore spaces, are generally known as the habitats of microbes and executes the physical constraints on enzymes, substrates, water and gas movement [4, 34]. Especially, in microaggregate, the physical constraint and enzyme activity are higher than those in macroaggregate and lower than those in silt-clay aggregates [29, 55]. Thus, the measurement of enzyme activity in microaggregate can not only reveal the conditions of $\mathrm{C}, \mathrm{N}$ and $\mathrm{P}$ cycles in soil, but also quantify the potential of the enzyme activity to perform soil nutrient bioavailability $[14,46]$.

Moreover, soil microaggregate in chestnut is generally thought to contain more stable $\mathrm{C}$ by physically impeding enzymatic degradation of $\mathrm{C}$-containing compounds as compared with other fractions of soil aggregates in bulk soil $[1,30,50]$. Because enzymes may be hindered contacting with the substrates through mineral absorption. In addition, roots and mycorrhizal fungal hyphae also play an important role in binding of microaggregate to format macroaggregates $[35,51,56]$. Therefore, the enzyme activity in microaggregate is a reliable indicator of the effects on soil stable $\mathrm{C}$ under enhanced $\mathrm{N}$ input.

In this study, we conducted a 7-year (2006-2012) $\mathrm{N}$ addition experiment to explore the effect of $\mathrm{N}$ addition on bulk soil enzyme activity and microbial community compositions as well as microaggregate enzyme activity at a temperate steppe in Inner Mongolian, China. The major objectives were to clarify the responses of: (1) the activities of soil enzymes (BG, NAG, LAP and AP) and microbial community compositions (total PLFAs, bacterial PLFAs, fungal PLFAs, actinomycete PLFAs and the ratios of F/B and $\mathrm{G}^{+} / \mathrm{G}^{-}$) to increased $\mathrm{N}$ addition in bulk soil, and (2) the activities of soil enzymes (BG, NAG, LAP and AP) and physiochemical properties to increased $\mathrm{N}$ addition in microaggregate. These studies will provide useful data for exploring management strategies for temperate steppe under increased $\mathrm{N}$ input scenario.

\section{OBJECTS AND METHODS}

\section{Experimental Site}

The experimental site is a temperate steppe located near the Inner Mongolia Grassland Ecosystem Research Station (IMGERS) in northern China $\left(43^{\circ} 38^{\prime} \mathrm{N}, 116^{\circ} 42^{\prime} \mathrm{E}, 1250 \mathrm{~m}\right.$ a.s.1.). The mean annual temperature during the long term (1980-2008) in the experimental site was $0.3 \pm 0.1^{\circ} \mathrm{C}$, with mean monthly temperature ranging from $-21.6^{\circ} \mathrm{C}$ (January) to $19^{\circ} \mathrm{C}$ (July). The mean annual precipitation was $345 \pm 86 \mathrm{~mm}$, and approximately $80 \%$ of annual precipitation was in growing season from May to September. The experiment area has been fenced against grazing by large animals since 1999. The soil was a chestnut soil in Chinese classification or Calcic-orthic Aridisol in US soil taxonomy classification system [67]. The perennial rhizomatous grass Leymus chinensis and the perennial 
bunchgrass Stipagrandis are the dominant plant species, accounting for $60-75 \%$ of the total aboveground biomass [68].

\section{Experimental Design}

The simulated $\mathrm{N}$ deposition experiments were conducted since 2006. There were six treatments with four replicates for each treatment. Each plot was $6 \mathrm{~m} \times 6 \mathrm{~m}$ in dimension, and arranged in a randomized block design. Each block included six $\mathrm{N}$ addition levels, including 0, 56, 112, 224, 392 and $560 \mathrm{~kg} \mathrm{~N}^{-1} \mathrm{yr}^{-1}$ ( $\mathrm{N}$ was added as the form of urea) and was separated by a $1 \mathrm{~m}$ buffer.

Previous studies indicated that the growth of plants in this temperate steppe was limited by the availability of both $\mathrm{N}$ and $\mathrm{P}[5,73,74]$. However, few $\mathrm{N}$ addition experiments have excluded the $\mathrm{P}$ limitation and we added $15.5 \mathrm{~kg} \mathrm{P} \mathrm{ha}^{-1} \mathrm{yr}^{-1}$ using $\mathrm{KH}_{2} \mathrm{PO}_{4}$ to ensure $\mathrm{N}$ as the only limiting nutrient. The fertilizer was thoroughly mixed with sand and then applied to the plot surface in late May or early June, 1-2 days before the rain in each year.

\section{Soil Sampling}

Soil samples were collected randomly in an "S" format at each sampling plot, and five samples per plot were collected. The upper $20 \mathrm{~cm}$ was collected from each plot. All soil samples from one site were combined to gain a representative sample. Then, the samples were sieved through a $2 \mathrm{~mm}$ mesh to remove roots, and then placed in plastic bags and stored at $4{ }^{\circ} \mathrm{C}$ and immediately transported to the laboratory.

\section{Microaggregate Sieving}

For each soil sample, subsamples fractionated into 53-250 $\mu \mathrm{m}$ microaggregates through wet sieving method [20]. Then, the wet microaggregates were frozen at $-20^{\circ} \mathrm{C}$ in case of spattering in freeze-dryer. Finally, microaggregates were lypholized at $-50^{\circ} \mathrm{C}$. Enzymatic analysis was conducted immediately after separation procedures were completed [1, 36, 52].

Soil moisture was determined as mass loss after drying the soil at $105^{\circ} \mathrm{C}$ for $24 \mathrm{~h}$. Part of the air-dried and sieved samples were prepared for the measurement of soil $\mathrm{pH}$ and total organic carbon. Soil $\mathrm{pH}$ was measured by a $\mathrm{pH}$ meter with a soil-water ratio of $1: 2.5$. Soil organic carbon and total nitrogen were measured by an elemental analyzer (Vario MAX CN, Elementar, Germany). For the measurement of soil inorganic $\mathrm{N}$, soil samples were extracted with $2 \mathrm{M} \mathrm{L}^{-1} \mathrm{KCl}$. The concentrations of nitrate $\mathrm{N}\left(\mathrm{NO}_{3}^{-}-\mathrm{N}\right)$ and ammonium $\mathrm{N}\left(\mathrm{NH}_{4}^{+}-\mathrm{N}\right)$ in the filtrates were determined using a flow injection auto analyzer (FIAstar 5000 Analyzer; Foss Tecator, Hillerød, Denmark). Soil total phosphorus was determined by $\mathrm{HClO}_{4}-\mathrm{H}_{2} \mathrm{SO}_{4}$ digestion molybdenum-stibium-anticolorimetric method. Available soil $\mathrm{P}$ was measured in the Olsen's method [46].

\section{Soil Enzyme Activity Analysis}

Soil enzymes involved in the cycling of $C(\beta-1,4-$ glucosidase), N ( $\beta$-1,4-N-acetylglucosaminidase, leucine aminopeptidase) and $\mathrm{P}$ (acid phosphatase) were assayed. Sample suspensions were prepared by 1 g soil (convert to dry weight) to $125 \mathrm{~mL}$ of $50 \mathrm{mM}$, $\mathrm{pH}$ 6.7, acetate buffer and homogenizing with a glass stick. The resultant suspensions were continuously stirred using a vortex agitator (Scientific Industries, Vortex Genie 5, USA) while $200 \mu \mathrm{L}$ of aliquots were dispensed in 96-well microplates: 8 replicate wells per sample per assay. The activities of 4 enzymes in bulk soil and microaggregate were assayed. The microplates were incubated in the dark at $20^{\circ} \mathrm{C}$ for $4 \mathrm{~h}$. To terminate the reaction, $10 \mu \mathrm{L}$ aliquot of $1.0 \mathrm{M} \mathrm{NaOH}$ was added to each well. One minute later, the fluorescence was measured using a microplate fluorimeter with $365 \mathrm{~nm}$ excitation and $450 \mathrm{~nm}$ emission filters. After correcting for negative control and quenching, the activities of the enzymes were expressed in a unit of nmol g $\mathrm{h}^{-1}[23,48]$.

\section{Soil Microbial Community Analysis}

Soil microbial community compositions were characterized by analyzing phospholipid fatty acid (PLFA) biomarkers. Phospholipid fatty acids were extracted, fractionated, and quantified from fresh soil equivalent to $8 \mathrm{~g}$ dry weight $[10,38]$. Total microbial biomass was determined using the total concentration of PLFAs (nmol g $\mathrm{g}^{-1}$ ). Specially, the PLFAs such as i15:0, a15:0, i16:0, i17:0, 16:1 $107 \mathrm{c}$, cy 17:0 and cy19:0 were used to represent bacterial biomarkers. The poly-

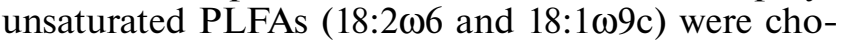
sen as fungal biomarkers. The fatty acids such as $10 \mathrm{Me} 18: 0$ and $10 \mathrm{Me} 16: 0$ were considered as the biomarkers of actinomycetes, and i15:0, a15:0, i16:0 and i17:0 were considered to be Gram-positive bacterial $\left(\mathrm{G}^{+}\right)$and $16: 1 \omega 7 \mathrm{c}$, cy 17:0 and cy 19:0 were considered to be Gram-negative bacterial $\left(\mathrm{G}^{-}\right)$biomarkers, respectively $[21,38,77]$.

\section{Enzyme Activity Calculation}

\author{
Activity $\left(\mathrm{nmolg}^{-1} \mathrm{~h}^{-1}\right)$ \\ Net Fluorescence $\times$ Buffer volume $(\mathrm{mL})$ \\ Emission coefficient $\times$ Homogenate Volume $(\mathrm{mL}) \times$ Time $(\mathrm{h}) \times$ Soil mass $(\mathrm{g})$.
}


Where,

$$
\text { Net Fluorescence }=\left(\frac{\text { Assay }- \text { Homogenate Control }}{\text { Quench Cofficient }}\right)
$$$$
\text { - Substrate Control; }
$$
Quench Coeff.

$$
=\frac{\text { Quench Control }- \text { Homogenate Control }}{\text { Standard Fluorescence }} \text { Q }
$$
$=\frac{\text { Slope of Curve (in presence of homogenate) }}{\text { Slope of Standard Curve (in presence of buffer) }}$.

Buffer volume is the volume of buffer used for homogenate preparation, and soil mass is the mass of soil added to the buffer.

\section{Data Analysis}

We used one-way analysis of variance (ANOVA) and Duncan's multiple comparison tests to determine the effects of different $\mathrm{N}$ treatments on soil $\mathrm{pH}$, soil organic carbon, total nitrogen, total phosphorus, $\mathrm{NH}_{4}^{+}-\mathrm{N}, \mathrm{NO}_{3}^{-}-\mathrm{N}$, available $\mathrm{P}\left(\mathrm{PO}_{4}^{3-}-\mathrm{P}\right)$ and soil enzyme activities. Data were represented as mean \pm standard error. Additionally, Pearson correlation coefficients were calculated to reveal the relationships among soil properties, enzyme activities, and microbial communities. The significant difference was considered at $p<0.05$. All analyses were carried out with SPSS 17.0 software (SPSS Inc., Chicago, IL, USA).

\section{RESULTS}

\section{Bulk Soil Response to N Addition}

Bulk soil chemical properties. In bulk soil, increased nitrogen significantly affected $\mathrm{pH}$, and SOC and $\mathrm{NH}_{4}^{+}-\mathrm{N}$ concentrations, however, no effect on total phosphorus (TP), total nitrogen (TN) and available phosphorus $\left(\mathrm{PO}_{4}^{3-}\right)$ concentration. It could decrease $\mathrm{pH}$ from 7.3 (N0) to 6.1 (N560). The SOC concentration showed a significant increase from $21.6 \mathrm{~g} \mathrm{~kg}^{-1}$ (N0) to $24.0 \mathrm{~g} \mathrm{~kg}^{-1}$ (N224) by $11 \%$. Ammonium $\left(\mathrm{NH}_{4}^{+}-\mathrm{N}\right)$ concentration showed a significant increase at $\mathrm{N} 392\left(82.35 \mathrm{mg} \mathrm{kg}^{-1}\right)$ and $\mathrm{N} 560$ $\left(86.33 \mathrm{mg} \mathrm{kg}^{-1}\right)$, while nitrate $\left(\mathrm{NO}_{3}^{-}-\mathrm{N}\right)$ concentration exhibited a large increase at N56, N112, N224 treatments and then showed a downtrend at N392 and N560 treatments (Table 1).

Bulk soil carbon, nitrogen and phosphorus-associated hydrolytic enzyme activity. In bulk soil, the activities of BG, NAG and LAP decreased significantly with the increased nitrogen except for AP activity. BG activity slightly decreased at the two low nitrogen addition levels (N56 and N112), and declined signifi- cantly at the N224 and the two higher levels (N392 and N560) of $\mathrm{N}$ addition (Fig. 1a). The activity of NAG at N560 level $\left(13 \mathrm{nmol} \mathrm{g}^{-1} \mathrm{~h}^{-1}\right)$ was significantly lower than that in the control (N0) of $27 \mathrm{nmol} \mathrm{g}^{-1} \mathrm{~h}^{-1}$ (Fig. 1b). The LAP activity declined significantly from N0 to N224, N392 and N560 by 43\%, 52\% and $63 \%$ at increasing nitrogen addition levels respectively (Fig. 1c). The activity of AP in bulk soil was not affected by nitrogen addition ranging from $75 \mathrm{nmol} \mathrm{g}^{-1} \mathrm{~h}^{-1}$ (N112) to $110 \mathrm{nmol} \mathrm{g}^{-1} \mathrm{~h}^{-1}$ (N224) (Fig. 1d).

Bulk Soil PLFA biomarkers. Compared with the controls, the content of total PLFAs was increased by 95\% when nitrogen addition reached up to $560 \mathrm{~kg} \mathrm{~N} \mathrm{ha}^{-1} \mathrm{yr}^{-1}$. On the average, bacteria constituted $67 \pm 4 \%$ of total microbial PLFAs in the field trial and ranged from $2.17 \mathrm{nmol} \mathrm{g}^{-1}$ (N0) to $4.53 \mathrm{nmol} \mathrm{g}^{-1}$ (N560). With nitrogen increasing, the fungal PLFA content had a rising trend and ranged from $0.83 \mathrm{nmol} \mathrm{g}^{-1}$ (N0) to $1.57 \mathrm{nmol} \mathrm{g}^{-1}$ (N560), but had obviously difference at all nitrogen addition levels. With the enhanced bacPLFAs and unchanged funPLFAs, the fungi-bacteria ratio showed a declining trend from 0.40 (N0) to 0.23 (N392).

Both $\mathrm{G}^{+}$and $\mathrm{G}^{-}$PLFA contents revealed a significant increase by nitrogen addition. Compared with the controls, $\mathrm{G}^{+}$PLFA and $\mathrm{G}^{-}$PLFA contents revealed the enhancement by $123 \%$ and $96 \%$ at the level of $\mathrm{N} 560$, respectively. $\mathrm{G}^{+} / \mathrm{G}^{-}$ratio was enhanced significantly at the level of N224 and varied from 1.23 to 1.63.

Correlation between bulk soil property and enzyme activity. The BG, NAG and LAP activities showed a positive relationship with $\mathrm{pH}(P<0.01)$, but a negative relationship with the concentrations of SOC and $\mathrm{NH}_{4}^{+}-\mathrm{N}$ under $\mathrm{N}$ addition $(P<0.05$; Table 2$)$. The AP activity was not correlated with soil $\mathrm{pH}$, and concen-

trations of SOC, TN, TP and $\mathrm{NH}_{4}^{+}-\mathrm{N}$. In addition, BG and LAP activities had a positive relationship with the concentration of TN. All soil enzyme activities were not significantly correlated with the concentration of TP in bulk soil $(P<0.05)$.

Correlation between bulk soil property and microbial community. Significantly negative correlation was found between total PLFAs (totPLFAs) and the concentration of $\mathrm{TN}$, while a positive relationship was found to the concentration of $\mathrm{NH}_{4}^{+}-\mathrm{N}$. The bacterial PLFAs (bacPLFAs) showed significant negative relationships with $\mathrm{pH}$ and the concentration of $\mathrm{TN}$, but significant positive relationship with the concentration of $\mathrm{NH}_{4}^{+}-\mathrm{N}$. Pearson correlation analysis showed that the actinomycete, Gram-positive bacterial $\left(\mathrm{G}^{+}\right)$, and Gram-negative bacterial PLFAs were all negatively correlated with the concentrations of $\mathrm{TN}$, but positively correlated with the concentration of $\mathrm{NH}_{4}^{+}$$\mathrm{N}$. There was a significant positive relationship between the $\mathrm{F} / \mathrm{B}$ ratio and the concentration of $\mathrm{TP}$. 
Table 1. Soil physicochemical properties (mean $\pm \mathrm{SE})$ in bulk soil $(0-20 \mathrm{~cm})$ and in microaggregate $(0-20 \mathrm{~cm})$ with different $N$ addition levels $(n=4)$

\begin{tabular}{l|l|l|l|l|l|l|l}
\hline $\begin{array}{c}\text { Treatment, } \\
\mathrm{kg} \mathrm{N} \mathrm{ha}^{-1} \mathrm{yr}^{-1}\end{array}$ & $\mathrm{pH}$ & $\begin{array}{c}\mathrm{SOC}, \\
\mathrm{g} \mathrm{kg}^{-1}\end{array}$ & $\begin{array}{c}\mathrm{TN}, \\
\mathrm{g} \mathrm{kg}^{-1}\end{array}$ & $\begin{array}{c}\mathrm{TP}, \\
\mathrm{g} \mathrm{kg}^{-1}\end{array}$ & $\begin{array}{c}\mathrm{NH}_{4}^{+}, \\
\mathrm{mg} \mathrm{kg}^{-1}\end{array}$ & $\begin{array}{c}\mathrm{NO}_{3}^{-}, \\
\mathrm{mg} \mathrm{kg}^{-1}\end{array}$ & $\begin{array}{c}\mathrm{PO}_{4}^{3-}, \\
\mathrm{mg} \mathrm{kg}^{-1}\end{array}$ \\
\hline $\mathrm{N}_{0}$ & $7.3 \pm 0.12 \mathrm{a}$ & $21.6 \pm 0.41 \mathrm{c}$ & $2.1 \pm 0.03 \mathrm{a}$ & $0.4 \pm 0.01 \mathrm{a}$ & $0.14 \pm 0.09 \mathrm{~b}$ & $11.51 \pm 0.27 \mathrm{c}$ & $10.81 \pm 1.39 \mathrm{a}$ \\
$\mathrm{N}_{56}$ & $6.7 \pm 0.07 \mathrm{ab}$ & $21.9 \pm 0.07 \mathrm{bc}$ & $2.1 \pm 0.07 \mathrm{a}$ & $0.4 \pm 0.01 \mathrm{a}$ & $1.35 \pm 1.06 \mathrm{~b}$ & $40.87 \pm 5.27 \mathrm{a}$ & $10.28 \pm 1.70 \mathrm{a}$ \\
$\mathrm{N}_{112}$ & $6.9 \pm 0.07 \mathrm{bc}$ & $22.6 \pm 0.43 \mathrm{~b}$ & $2.1 \pm 0.03 \mathrm{a}$ & $0.4 \pm 0.01 \mathrm{a}$ & $7.54 \pm 4.02 \mathrm{~b}$ & $49.70 \pm 5.51 \mathrm{a}$ & $8.75 \pm 0.87 \mathrm{a}$ \\
$\mathrm{N}_{224}$ & $6.4 \pm 0.17 \mathrm{c}$ & $24.0 \pm 0.22 \mathrm{a}$ & $2.1 \pm 0.07 \mathrm{a}$ & $0.3 \pm 0.01 \mathrm{a}$ & $15.87 \pm 9.11 \mathrm{~b}$ & $41.27 \pm 4.25 \mathrm{a}$ & $9.03 \pm 1.18 \mathrm{a}$ \\
$\mathrm{N}_{392}$ & $6.4 \pm 0.07 \mathrm{~cd}$ & $23.6 \pm 0.34 \mathrm{a}$ & $2.0 \pm 0.08 \mathrm{a}$ & $0.4 \pm 0.01 \mathrm{a}$ & $82.35 \pm 13.03 \mathrm{a}$ & $28.87 \pm 0.74 \mathrm{~b}$ & $10.12 \pm 1.84 \mathrm{a}$ \\
$\mathrm{N}_{560}$ & $6.1 \pm 0.15 \mathrm{~d}$ & $23.7 \pm 0.28 \mathrm{a}$ & $2.1 \pm 0.08 \mathrm{a}$ & $0.4 \pm 0.01 \mathrm{a}$ & $86.33 \pm 15.68 \mathrm{a}$ & $29.54 \pm 1.65 \mathrm{~b}$ & $10.90 \pm 1.82 \mathrm{a}$ \\
& & & In microaggregate & & & \\
$\mathrm{N}_{0}$ & $7.5 \pm 0.13 \mathrm{a}$ & $16.6 \pm 1.00 \mathrm{ab}$ & $1.6 \pm 0.15 \mathrm{a}$ & $0.3 \pm 0.03 \mathrm{ab}$ & $17.74 \pm 1.59 \mathrm{~b}$ & $1.05 \pm 0.47 \mathrm{a}$ & $0.28 \pm 0.03 \mathrm{ab}$ \\
$\mathrm{N}_{56}$ & $7.1 \pm 0.03 \mathrm{~b}$ & $16.4 \pm 0.84 \mathrm{ab}$ & $1.6 \pm 0.15 \mathrm{a}$ & $0.3 \pm 0.02 \mathrm{a}$ & $20.51 \pm 0.66 \mathrm{~b}$ & $1.52 \pm 0.40 \mathrm{a}$ & $0.26 \pm 0.10 \mathrm{ab}$ \\
$\mathrm{N}_{112}$ & $7.1 \pm 0.09 \mathrm{~b}$ & $17.3 \pm 1.14 \mathrm{a}$ & $1.7 \pm 0.07 \mathrm{a}$ & $0.4 \pm 0.02 \mathrm{a}$ & $28.33 \pm 6.32 \mathrm{~b}$ & $1.24 \pm 0.50 \mathrm{a}$ & $0.22 \pm 0.04 \mathrm{ab}$ \\
$\mathrm{N}_{224}$ & $6.9 \pm 0.17 \mathrm{bc}$ & $16.2 \pm 0.31 \mathrm{ab}$ & $1.7 \pm 0.03 \mathrm{a}$ & $0.3 \pm 0.03 \mathrm{a}$ & $30.76 \pm 3.97 \mathrm{~b}$ & $1.66 \pm 0.33 \mathrm{a}$ & $0.33 \pm 0.04 \mathrm{a}$ \\
$\mathrm{N}_{392}$ & $6.7 \pm 0.09 \mathrm{c}$ & $14.5 \pm 0.92 \mathrm{bc}$ & $1.5 \pm 0.09 \mathrm{ab}$ & $0.3 \pm 0.03 \mathrm{ab}$ & $48.82 \pm 3.33 \mathrm{a}$ & $1.24 \pm 0.30 \mathrm{a}$ & $0.29 \pm 0.04 \mathrm{ab}$ \\
$\mathrm{N}_{560}$ & $6.7 \pm 0.05 \mathrm{c}$ & $12.2 \pm 0.50 \mathrm{c}$ & $1.3 \pm 0.05 \mathrm{~b}$ & $0.2 \pm 0.01 \mathrm{~b}$ & $44.93 \pm 5.99 \mathrm{a}$ & $1.20 \pm 0.26 \mathrm{a}$ & $0.14 \pm 0.02 \mathrm{~b}$ \\
\hline
\end{tabular}

Soil $\mathrm{pH}$ was measured with a soil-water ratio of $1: 2.5$. SOC: soil organic carbon; TN: total nitrogen; TP: total phosphorus. Different letters in each row indicate significant differences $(P<0.05)$ of means under different $N$ additions.

The $\mathrm{G}^{+} / \mathrm{G}^{-}$ratio had a significantly negative relationship with soil $\mathrm{pH}$, but a significantly positive relationship with the concentration of SOC.

\section{Microaggregate Response to $N$ Addition}

Microaggregate chemical properties. Contrast with the bulk soil, we found that SOC concentration in microaggregate was decreased significantly with the increased $\mathrm{N}$ levels. Microaggregate $\mathrm{pH}$, total nitrogen (TN) and total phosphorus (TP) concentrations were significantly lower in the nitrogen treatment than the control $(P<0.05)$. But nitrate $\left(\mathrm{NO}_{3}^{-}\right)$concentration and available phosphorus $\left(\mathrm{PO}_{4}^{3-}\right)$ concentration were not significant influenced by $\mathrm{N}$ increase. Nitrogen input resulted in a decrease of microaggregate $\mathrm{pH}$ by $11 \%$ from 7.5 (N0) to 6.7 (N392 and N560). The SOC concentration revealed a significant decrease from 16.6 (N0) to $12.2 \mathrm{~g} \mathrm{~kg}^{-1}$ (N560) by $27 \%$ with nitrogen amendment. Ammonium $\left(\mathrm{NH}_{4}^{+}-\mathrm{N}\right)$ concentrations showed a significant increase at the highest rate of $48.82 \mathrm{mg} \mathrm{kg}^{-1}(\mathrm{~N} 392)$ while nitrate $\left(\mathrm{NO}_{3}^{-}-\mathrm{N}\right)$ concentrations were not significantly shifted according with nitrogen increase and varied from $1.05 \mathrm{mg} \mathrm{kg}^{-1}$ (N0) to 1.66 (N224). The concentration of available phospho- rus $\left(\mathrm{PO}_{4}^{3-}\right)$ was not influenced by nitrogen supply and varied from 0.33 (N224) to $0.14 \mathrm{~g} \mathrm{~kg}^{-1}$ (N560).

Microaggregate enzyme activity. In microaggregate, nitrogen addition had no significant effects on BG, NAG and AP activities except for LAP activity $(P<0.05$; Fig. 2). All activities of BG, NAG and AP tended to increase along the low levels of $\mathrm{N}$ addition, peaked at the N112 level (BG) or N224 level (NAG and AP), and then decreased at the highest $\mathrm{N}$ addition level. LAP activities at N392 and N560 treatment were significantly lower than that at the control (N0) and N56 treatment $(P<0.05$; Fig. $2 \mathrm{c})$.

Correlation between soil property and soil enzyme activity in microaggregate. Significantly positive relationships were found between the activity of BG and the concentrations of SOC, TN and TP in microaggregate. The LAP activity showed significant positive correlations with microaggregate $\mathrm{pH}$ and the concentration of SOC, but a significant negative correlation with the concentration of $\mathrm{NH}_{4}^{+}-\mathrm{N}$. Pearson correlation analysis showed that the activity of AP was not significantly related to microaggregate $\mathrm{pH}$, and the concentrations of SOC, TN and $\mathrm{NH}_{4}^{+}-\mathrm{N}$. However, significantly positive correlation was found between AP activity and the concentration of TP in microaggregate. 




$\mathrm{LAP}, \mathrm{nmol} /(\mathrm{g} \mathrm{h})$

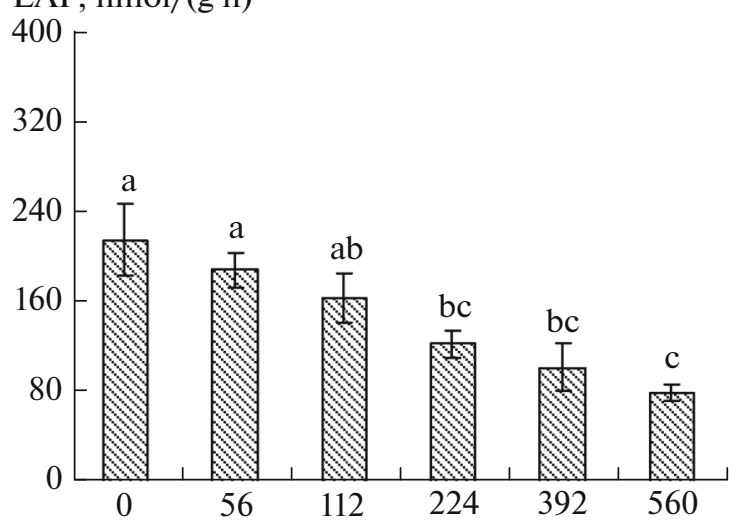

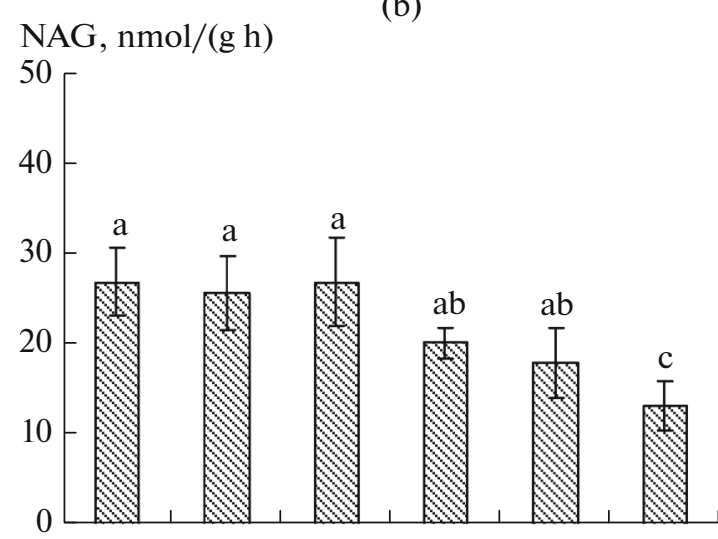

(d)

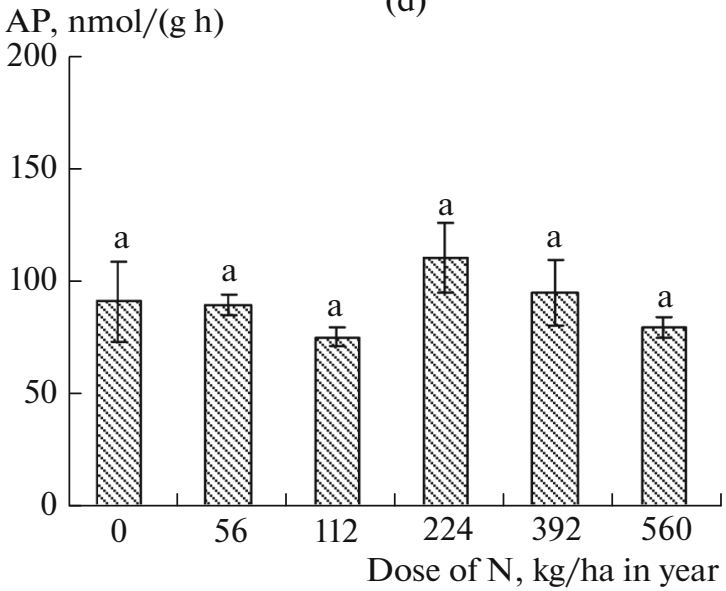

Fig. 1. The effect of $\mathrm{N}$ addition on (a) BG, (b) NAG, (c) LAP and (d) AP activities (mean \pm SE) in bulk soil. Note: BG, $\beta-1,4-$ glucosidase; NAG, $\beta$-1,4-N-acetylglucosaminidase; LAP, L-leucine aminopeptidase; AP, acid phosphatase. N0: No N addition as the control; N56: $56 \mathrm{~kg} \mathrm{~N} \mathrm{ha}^{-1} \mathrm{yr}^{-1}$; N112: $112 \mathrm{~kg} \mathrm{~N} \mathrm{ha}^{-1} \mathrm{yr}^{-1}$; N224: $224 \mathrm{~kg} \mathrm{~N} \mathrm{ha}^{-1} \mathrm{yr}^{-1}$; N392: $392 \mathrm{~kg} \mathrm{~N} \mathrm{ha}^{-1} \mathrm{yr}^{-1}$; N560: $560 \mathrm{~kg} \mathrm{~N} \mathrm{ha}^{-1} \mathrm{yr}^{-1}$. Lowercase letters indicate the significant differences $(P<0.05)$ among different $\mathrm{N}$ addition levels.

\section{DISCUSSION}

\section{Soil Enzyme Activity Response to Long-term N Addition in Bulk Soil}

Previous studies have shown that BG and AP activities were not responsive until $\mathrm{N}$ addition reached the amount of $150 \mathrm{~kg} \mathrm{~N} \mathrm{ha}^{-1} \mathrm{yr}^{-1}$ and $100 \mathrm{~kg} \mathrm{~N} \mathrm{ha}^{-1} \mathrm{yr}^{-1}$ in Inner Mongolia, respectively [7, 67]. As compare with previous results, our studies have described that $\mathrm{BG}$ activity did not exhibit a significant decrease until $\mathrm{N}$ addition reached up to the amount of $224 \mathrm{~kg} \mathrm{~N} \mathrm{ha}^{-1} \mathrm{yr}^{-1}$ (Fig. 1). The suppressed BG activity may be due to alleviation of limited carbon (C). Exceed $\mathrm{N}$ supply $\left(>224 \mathrm{~kg} \mathrm{~N} \mathrm{ha}^{-1} \mathrm{yr}^{-1}\right.$ ) was probably stimulated plant growing and enhance soil C by increased plant litter [63, 80], which results in the indirect impact of $\mathrm{N}$ addition on soil microbial $\mathrm{C}$ acquisition [16]. The support for this idea comes from the increasing SOC concentration. In addition, there was no significant effect of $\mathrm{N}$ input on AP activity and this may be due to the addition of $\mathrm{P}\left(15.5 \mathrm{~kg} \mathrm{P} \mathrm{ha}^{-1} \mathrm{yr}^{-1}\right.$ for all treatments) at the beginning of the experiments, thus microbes could obtain enough $\mathrm{P}$ to satisfy their living requirements without decomposing organic matter to obtain extra $\mathrm{PO}_{4}^{3-}-\mathrm{P}$.

The amount of $\mathrm{N}$ addition does not result in the reduction of NAG and LAP activity less than $560 \mathrm{~kg} \mathrm{~N} \mathrm{ha}^{-1} \mathrm{yr}^{-1}$ and $224 \mathrm{~kg} \mathrm{~N} \mathrm{ha}^{-1} \mathrm{yr}^{-1}$ respectively for Inner Mongolia grassland soil. Bowles et al. have reported that higher inorganic $\mathrm{N}$ availability could reduce the activity of enzymes involved directly in $\mathrm{N}$ mineralization in agricultural system [11], which is good agreement with our results of reduced NAG and LAP activities along with the significantly increased $\mathrm{NO}_{3}^{-}-\mathrm{N}$ and $\mathrm{NH}_{4}^{+}-\mathrm{N}$ concentrations. The enhancement of $\mathrm{N}$ availability offers plants to access $\mathrm{N}$ resources easily [64]. Under the condition of increased inorganic nitrogen concentration, plants apparently no longer depend on soil microbes in acquiring $\mathrm{N}$ resources so that the activities of $\mathrm{N}$-acquiring enzymes such as NAG and LAP present an obvious decrease during $\mathrm{N}$ addition [40]. Additionally, the reduction of soil $\mathrm{pH}$ may also play a critical role through controlling the production of enzymes, ionization- 
Table 2. Pearson correlation analysis among soil properties, soil enzyme activities and microbial variables in bulk soil and in microaggregate

\begin{tabular}{|c|c|c|c|c|c|}
\hline Parameter & $\mathrm{pH}$ & $\mathrm{SOC}, \mathrm{g} \mathrm{kg}^{-1}$ & $\mathrm{TN}, \mathrm{g} \mathrm{kg}^{-1}$ & $\mathrm{TP}, \mathrm{g} \mathrm{kg}^{-1}$ & $\mathrm{NH}_{4}^{+}, \mathrm{mg} \mathrm{kg}^{-1}$ \\
\hline \multicolumn{6}{|c|}{ In bulk soil } \\
\hline BG & $0.945^{* *}$ & $-0.836^{*}$ & $0.862^{*}$ & 0.549 & $-0.929 * *$ \\
\hline NAG & $0.934^{* *}$ & $-0.828^{*}$ & 0.678 & 0.342 & $-0.899^{*}$ \\
\hline LAP & $0.951^{* *}$ & $-0.929 * *$ & $0.818^{*}$ & 0.364 & $-0.871^{*}$ \\
\hline AP & -0.121 & 0.334 & 0.218 & 0.090 & -0.115 \\
\hline totPLFAs & -0.763 & 0.716 & $-0.894^{*}$ & -0.256 & $0.827^{*}$ \\
\hline bacPLFAs & $-0.813^{*}$ & 0.747 & $-0.942^{* *}$ & -0.431 & $0.910^{*}$ \\
\hline funPLFAs & -0.415 & 0.417 & -0.521 & 0.306 & 0.391 \\
\hline actPLFAs & -0.666 & 0.557 & $-0.934^{*}$ & -0.687 & $0.950^{*}$ \\
\hline $\mathrm{G}^{+}$PLFAs & $-0.860^{*}$ & 0.811 & $-0.940^{* *}$ & -0.464 & $0.922^{* *}$ \\
\hline $\mathrm{G}^{-} \mathrm{PLFAs}$ & -0.702 & 0.612 & $-0.908^{*}$ & -0.339 & $0.849^{*}$ \\
\hline $\mathrm{F} / \mathrm{B}$ ratio & 0.719 & -0.501 & 0.483 & $0.857^{*}$ & -0.737 \\
\hline $\mathrm{G}^{+} / \mathrm{G}^{-}$ratio & $-0.816^{*}$ & $0.916^{*}$ & -0.476 & -0.325 & 0.537 \\
\hline \multicolumn{6}{|c|}{ In microaggregate } \\
\hline BG & 0.493 & $0.907^{*}$ & $0.853^{*}$ & $0.916^{*}$ & 0.655 \\
\hline NAG & -0.323 & -0.021 & 0.187 & 0.087 & 0.386 \\
\hline LAP & $0.935^{* *}$ & $0.841^{*}$ & 0.671 & 0.544 & $-0.977^{*}$ \\
\hline AP & -0.089 & 0.578 & 0.780 & 0.863 & -0.146 \\
\hline
\end{tabular}

* indicates significant difference at $P<0.05$,** indicates significant difference at $P<0.01$.

induced conformational changes of enzymes, and/or availability of substrates and enzymatic co-factors in soil $[67,72]$.

Although increased available nitrogen input can stimulate microbial growth and increase potential enzyme activities, some environmental factors such as decreased soil $\mathrm{pH}$ and water availability may be have negative effects on soil enzyme activity [19, 79]. Pearson correlation analysis between soil enzyme activities and soil $\mathrm{pH}$ has shown that the activities of BG, NAG and LAP were significantly positively correlated with soil $\mathrm{pH}$. Previous experiments have demonstrated that plant growth response may be an important factor. Considering the increasing aboveground plant biomass by $\mathrm{N}$ addition, the increased leaf transpiration associated with greater growth rate can reduce soil water availability, thus suppressing enzyme activity [71]. Because decreased soil water availability can limit enzyme and substrate diffusion [80].

\section{Soil Microbial Community Response to Long-Term N Addition in Bulk Soil}

Our results have indicated that $\mathrm{N}$ addition (392 $\mathrm{kg} \mathrm{N} \mathrm{ha}^{-1} \mathrm{yr}^{-1}$ ) can significantly increase soil microbial community (Fig. 2). The increased microbial community is likely due to the increased carbon input from aboveground litter production by enhanc- ing $\mathrm{N}$ availability, especially in semi-arid temperate steppe with the limited available $\mathrm{N}$ [25, 63]. It is consistent with our results that bacPLFAs (also for $\mathrm{G}^{+}$PLFAs) is negatively correlated with soil $\mathrm{pH}$ and totPLFAs is significantly positively correlated with the concentration of $\mathrm{NH}_{4}^{+}-\mathrm{N}$ in bulk soil. Demoling et al. [18] have reported that nitrogen addition can decrease soil $\mathrm{pH}$, resulting in the leaching of magnesium and calcium and the mobilization of aluminum. In this way, microbes may be limited by magnesium or calcium, or may experience aluminum toxicity. Therefore, microbial growth could be inhibited by $\mathrm{N}$ addition indirectly. Similarly, microbes may not be limited by the same element such as N [27], and may be limited by carbon, water or phosphorus [53, 31]. In addition, we have added $15.5 \mathrm{~kg} \mathrm{P} \mathrm{ha}^{-1} \mathrm{yr}^{-1}$ as $\mathrm{KH}_{2} \mathrm{PO}_{4}$ in all $\mathrm{N}$ addition treatments in order to exclude the soil $\mathrm{P}$ limitation at the beginning of the experiment and soil water availability is consistent among all treatments. Therefore, the limitation of $\mathrm{C}$ of microbes associated with $\mathrm{N}$ addition may play a critical role. As us well known, the production of aboveground plant litter usually increases $\mathrm{N}$ input [39]. Plant community compositions also shift towards species with greater litter quality [59, 62], which could alleviate carbon limitation as plant litter incorporated into soil. Thus, microbial community may be enhanced by $\mathrm{N}$ addition through $\mathrm{C}$ alleviation. 
(a)

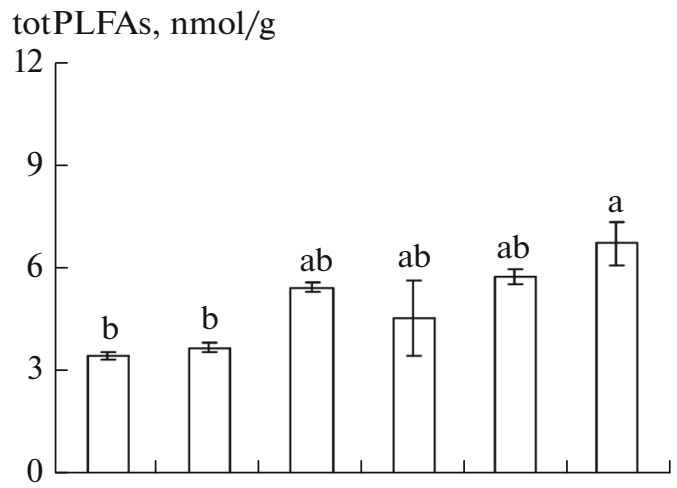

(c)

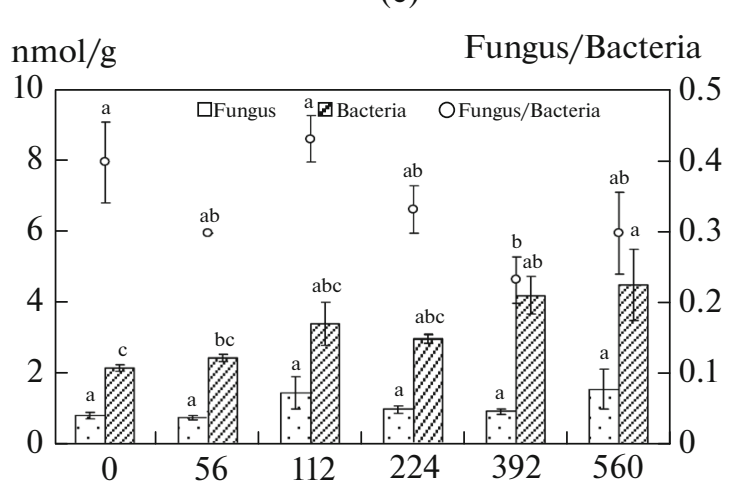

(b)

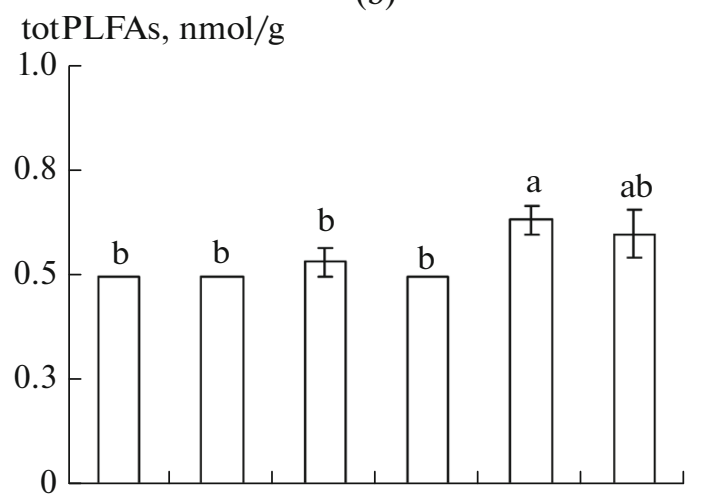

(d)

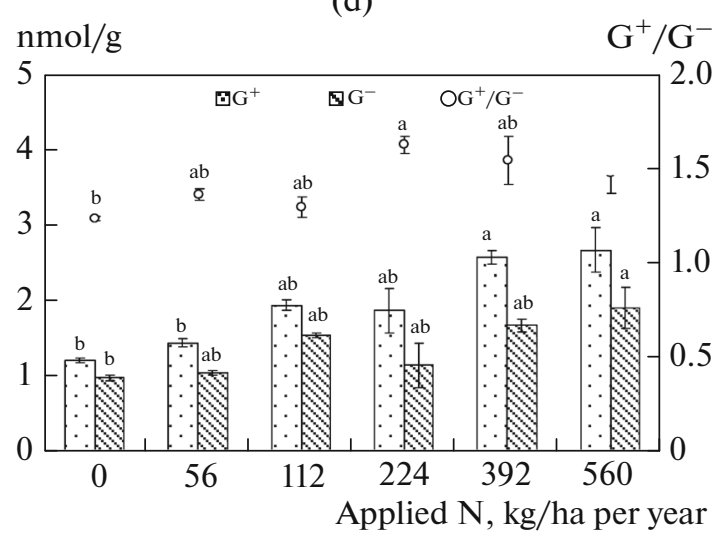

Fig. 2 The effect of $\mathrm{N}$ addition on (a) totPLFAs, (b) actPLFAs, (c) funPLFAs, bacPLFAs and fungi-bacteria (F/B) ratio, (D) $\mathrm{G}^{+}$PLFAs, $\mathrm{G}^{-}$PLFAs and $\mathrm{G}^{+} / \mathrm{G}^{-}$ratio (mean $\pm \mathrm{SE}$ ) in bulk soil. Note: totPLFAs: total PLFAs; bacPLFAs: bacterial PLFAs; actPLFAs: actinomycete PLFAS; funPLFAs: fungal PLFAs; $\mathrm{G}^{+}$PLFAs: positive gram bacterial PLFAs; ${ }^{-}{ }^{-}$PLFAs: negative gram bacterial PLFAs. Lowercase letters indicate the significant differences $(P<0.05)$ among different $\mathrm{N}$ addition levels.

Changes in F/B ratios have implications for microbial turnover and $\mathrm{N}$ mineralization. Decreasing the abundance of fungi relative to bacteria should favor $\mathrm{N}$ immobilization, because the $\mathrm{C} / \mathrm{N}$ ratio of bacterial biomass is lower than that of fungal hyphae [9]. Thus, bacterial growing needs more available $\mathrm{N}$ than fungal. In the present study, the reduction of soil $\mathrm{F} / \mathrm{B}$ ratio by $\mathrm{N}$ addition may result from the impact of high levels of inorganic $\mathrm{N}\left(\mathrm{NH}_{4}^{+}-\mathrm{N}\right.$ and $\left.\mathrm{NO}_{3}^{-}-\mathrm{N}\right)$ availability [15]. Correspondingly, our results have showed that $\mathrm{N}$ addition significantly enhanced both $\mathrm{NH}_{4}^{+}-\mathrm{N}$ and $\mathrm{NO}_{3}^{-}-\mathrm{N}$ concentrations when $\mathrm{N}$ addition reached up to $392 \mathrm{~kg} \mathrm{~N}$ ha $^{-1} \mathrm{yr}^{-1}$. The decreased $\mathrm{F} / \mathrm{B}$ ratios under increasing $\mathrm{N}$ additions have been obtained in many experiments on similar soils $[7,9,15,47,78]$. These results have indicated decreases in both funPLFAs and bacPLFAs, which mainly due to the better adaptation of fungi to acidity than bacteria. Despite $\mathrm{N}$ addition reduced the soil $\mathrm{pH}$ in our experiment, we found that the $\mathrm{F} / \mathrm{B}$ ratio decreased caused by an increasing bacPLFAs rather than a decreasing funPLFAs (Fig. 2). The increased bacterial PLFAs suggested that the bacterial compounds degraders were previously limited by nitrogen and the increased available $\mathrm{N}$ enabled bacteria increase significantly. In addition, the negative effect of decreased $\mathrm{pH}$ on bacPLFAs was inferior to the positive effect of available $\mathrm{N}$ and these reasons combines leading to a decrease of $\mathrm{F} / \mathrm{B}$ ratio with $\mathrm{N}$ inputs. Our result showed that $\mathrm{N}$ input have significantly reduced the $\mathrm{F} / \mathrm{B}$ ratio ranging from 0.40 (N0) to 0.23 (N392). Similar short-term experiments have been conducted on chestnut in the grassland of China. Bi J's results showed that the ratio of $\mathrm{F} / \mathrm{B}$ declined from 0.12 (control) to 0.09 (100 $\mathrm{kg} \mathrm{N} \mathrm{ha}^{-1} \mathrm{yr}^{-1}$ ) when $\mathrm{N}$ added [7]. Another experiment by Zhang $\mathrm{N}$ also indicated a reduced $\mathrm{F} / \mathrm{B}$ ratio changing from 0.26 (control) to $0.24\left(150 \mathrm{~kg} \mathrm{~N} \mathrm{ha}^{-1} \mathrm{yr}^{-1}\right)$ under $\mathrm{N}$ input [78]. The F/B ratio in the control and $\mathrm{N}$ treatment of our experiment were higher than that of their results. It is possible that there was high SOC concentration $\left(21.6 \mathrm{~g} \mathrm{~kg}^{-1}\right)$ as compare with the SOC concentration of Bi J (15.52 $\left.\mathrm{g} \mathrm{kg}^{-1}\right)$ and Zhang $\mathrm{N}\left(9.7 \mathrm{~g} \mathrm{~kg}^{-1}\right)$ [7, 78]. It is generally known that fungus use carbon more efficiently and the soil with a higher soil $\mathrm{C}$ storage often has a higher F/B ratio [47]. 


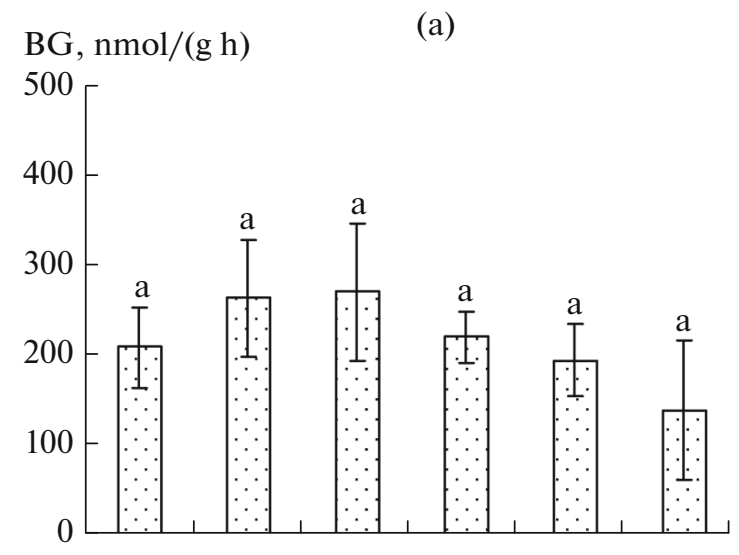

(c)

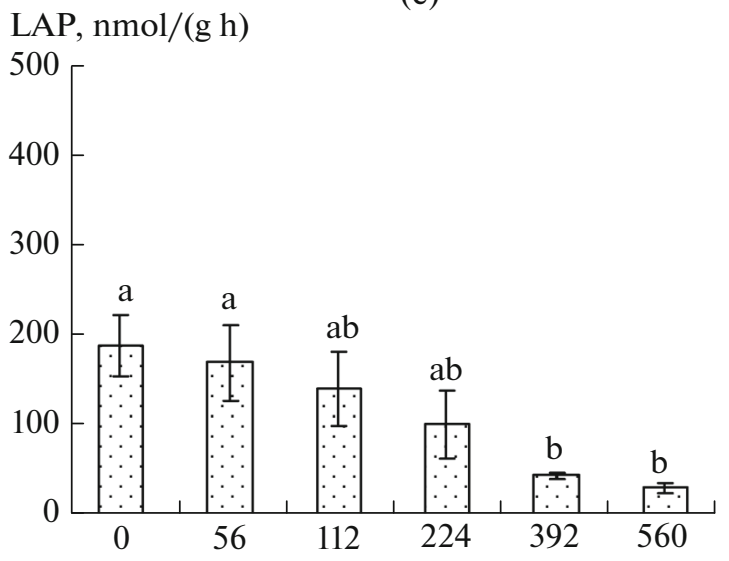

$\mathrm{NAG}, \mathrm{nmol} /(\mathrm{g} \mathrm{h})$

(b)

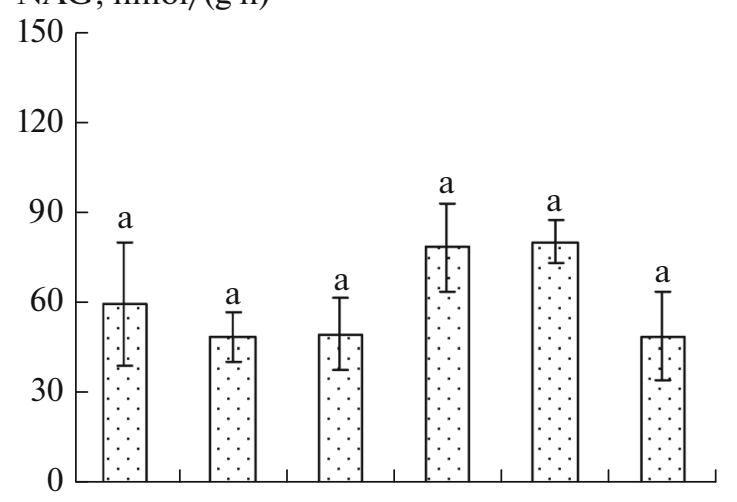

(d)



Fig. 3. The effect of $\mathrm{N}$ addition on (a) BG activity, (b) NAG activity, (c) LAP activity and (d) AP activity (mean \pm SE) in microaggregate. Note: BG, $\beta$-1,4-glucosidase; NAG, $\beta-1,4-\mathrm{N}$-acetylglucosaminidase; LAP, L-leucine aminopeptidase; AP, acid phosphatase. N0: No N addition as the control; N56: $56 \mathrm{~kg} \mathrm{~N} \mathrm{ha}^{-1} \mathrm{yr}^{-1}$; N112: $112 \mathrm{~kg} \mathrm{~N} \mathrm{ha}^{-1} \mathrm{yr}^{-1} ; \mathrm{N}^{2} 24: 224 \mathrm{~kg} \mathrm{~N} \mathrm{ha}^{-1} \mathrm{yr}^{-1}$; N392: $392 \mathrm{~kg} \mathrm{~N} \mathrm{ha}^{-1} \mathrm{yr}^{-1}$; N560: $560 \mathrm{~kg} \mathrm{~N} \mathrm{ha}^{-1} \mathrm{yr}^{-1}$. Lowercase letters indicate the significant differences $(P<0.05)$ among different $\mathrm{N}$ addition levels.

\section{Soil Enzyme Activity Response to Long-term N Addition in Microaggregate}

$\mathrm{BG}, \mathrm{NAG}$ and AP activities in microaggregate were not significantly affected by $\mathrm{N}$ addition. It was mainly due to the physical protection, which can prevent enzymes from contacting with the substrate. As the effects of mineral absorption and roots and mycorrhizal fungal hyphae, the process of enzymes degrading complex compounds into smaller products will be impeded [57]. The substrate may be restricted by compound and the conformation of enzymes in microaggregate would be changed associated with mineral absorption as well $[1,4]$. In addition, the decrease in $\mathrm{pH}$ of microaggregate due to $\mathrm{N}$ addition is not significantly correlated with BG, NAG and AP activities, which may be resulted from the impact that the response of enzyme activity to chemical properties is stronger than that to decreased $\mathrm{pH}$ in microaggregate. Contrast with the nonresponsive BG, NAG and AP activities of $\mathrm{N}$ increase, LAP activity showed a significant reduction in the presence of $\mathrm{N}$ addition. As shown, LAP activity is significantly negatively correlated with the concentration of $\mathrm{NH}_{4}^{+}-\mathrm{N}$. Although LAP and NAG enzymes are both indicators of $\mathrm{N}$ uptake, their activities are also depends on substrate availability, which can be altered by $\mathrm{N}$ addition. Moreover, the significantly changed soil physiochemical properties by $\mathrm{N}$ addition may result in an interactive effect on NAG and LAP enzymes [12], which may be the explanation of opposite response between NAG and LAP to $\mathrm{N}$ addition in microaggregate.

\section{CONCLUSIONS}

With $\mathrm{N}$ increasing, the activities of BG, NAG and LAP have shown a declining trend in bulk soil. Moreover, significant positive relationship is observed between bulk soil BG, NAG, LAP activities and bulk soil $\mathrm{pH}$ respectively, but significant negative relationships is found between bulk soil SOC and $\mathrm{NH}_{4}^{+}-\mathrm{N}$ concentrations. The suppressed BG, NAG and LAP 
activities in bulk soil can due to the increased bulk soil

SOC, $\mathrm{NH}_{4}^{+}-\mathrm{N}$ concentrations and decreased soil $\mathrm{pH}$. Besides, $\mathrm{N}$ addition can significantly enhance totPLFAs and bacPLFAs at N392 treatments in bulk soil. The increased soil total PLFAs and bacterial PLFAs are mainly due to the elevated available carbon from aboveground litter by N supply. However, no significant response of BG and NAG activities is detected in microaggregate except LAP activity reveals a significant reduction. Therefore, LAP activity in microaggregate may be a good indicator for assessing $\mathrm{N}$ cycling of microaggregate in response to long-term $\mathrm{N}$ addition.

\section{ACKNOWLEDGMENTS}

This study was jointly financed by the program of National Natural Science Foundation of China (nos. 31130009, 31290222 and 41171153), and the Key Project in Knowledge Innovation Program of the Chinese Academy of Sciences (no. KZCX2-EW-310).

\section{REFERENCES}

1. S. D. Allison and J. D. Jastrow, "Activities of extracellular enzymes in physically isolated fractions of restored grassland soils," Soil Biol. Biochem. 38 (11), 32453256 (2006).

2. C. J. Alster, D. P. German, Y. Lu, and S. D. Allison, "Microbial enzymatic responses to drought and to nitrogen addition in a southern California grassland," Soil Biol. Biochem. 64 (9), 68-79 (2013).

3. M. P. Babaev and N. I. Orujova, "Assessment of the biological activity of soils in the subtropical zone of Azerbaijan," Eurasian Soil Sci. 42 (10), 1163-1169 (2009).

4. E. M. Bach and K. S. Hofmockel, "Soil aggregate isolation method affects measures of intra-aggregate extracellular enzyme activity," Soil Biol. Biochem. 69 (1), 54-62 (2014).

5. Y. Bai, J. Wu, C. M. Clark, et al., "Tradeoffs and thresholds in the effects of nitrogen addition on biodiversity and ecosystem functioning: evidence from Inner Mongolia grasslands," Global Change Biol. 16 (1), 358-372 (2010).

6. P. Baldrian, J. Voříšková, P. Dobiášová, V. Merhautová, L. Lisá, and V. Valášková, "Production of extracellular enzymes and degradation of biopolymers by saprotrophic microfungi from the upper layers of forest soil," Plant Soil 338 (1-2), 111-125 (2011).

7. J. Bi, N. Zhang, Y. Liang, H. Yang, and K. Ma, "Interactive effects of water and nitrogen addition on soil microbial communities in a semiarid steppe," J. Plant Ecol. 5 (3), 320-329 (2012).

8. S. A. Billings, C. M. Brewer, and B. L. Foster, "Incorporation of plant residues into soil organic matter fractions with grassland management practices in the North American Midwest," Ecosystems 9 (5), 805-815 (2006).
9. S. Bittman, T. A. Forge, and C. G. Kowalenko, "Responses of the bacterial and fungal biomass in a grassland soil to multi-year applications of dairy manure slurry and fertilizer," Soil Biol. Biochem. 37 (4), 613-623 (2005).

10. D. A. Bossio and K. M. Scow, "Impacts of carbon and flooding on soil microbial communities: phospholipid fatty acid profiles and substrate utilization patterns," Microb. Ecol. 35 (3-4), 265-278 (1998).

11. T. M. Bowles, V. Acosta-Martínez, F. Calderón, and L. E. Jackson, "Soil enzyme activities, microbial communities, and carbon and nitrogen availability in organic agroecosystems across an intensively-managed agricultural landscape," Soil Biol. Biochem. 68 (1), 252-262 (2014).

12. R. G. Burns, J. L. DeForest, J. Marxsen, et al., "Soil enzymes in a changing environment: current knowledge and future directions," Soil Biol. Biochem. 58 (2), 216-234 (2013).

13. R. Cahan, E. Hetzroni, M. Nisnevitch, and Y. Nitzan, "Purification and Identification of a novel leucine aminopeptidase from Bacillus thuringiensis israelensis," Curr. Microbiol. 55 (5), 413-419 (2007).

14. R. Cardelli, R. Levi-Minzi, A. Saviozzi, and R. Riffaldi, "Organically and conventionally managed soils: biochemical characteristics," J. Sustainable Agric. 25 (2), 63-74 (2005).

15. F. T. De Vries, E. Hoffland, N. van Eekeren, L. Brussaard, and J. Bloem, "Fungal/bacterial ratios in grasslands with contrasting nitrogen management," Soil Biol. Biochem. 38 (8), 2092-2103 (2006).

16. J. L. DeForest, D. R. Zak, K. S. Pregitzer, and A. J. Burton, "Atmospheric nitrate deposition, microbial community composition, and enzyme activity in northern hardwood forests," Soil Sci. Soc. Am. J. 68 (1), 132-138 (2004).

17. F. Demoling, D. Figueroa, and E. Bååth, "Comparison of factors limiting bacterial growth in different soils," Soil Biol. Biochem. 39 (10), 2485-2495 (2007).

18. F. Demoling, L. Ola Nilsson, and E. Bååth, "Bacterial and fungal response to nitrogen fertilization in three coniferous forest soils," Soil Biol. Biochem. 40 (2), 370-379 (2008).

19. W. A. Dick, L. Cheng, and P. Wang, "Soil acid and alkaline phosphatase activity as $\mathrm{pH}$ adjustment indicators," Soil Biol. Biochem. 32 (13), 1915-1919 (2000).

20. E. T. Elliott, "Aggregate structure and carbon, nitrogen, and phosphorus in native and cultivated soils," Soil Sci. Soc. Am. J. 50 (3), 627-633. 1986.

21. Å. Frostegård and E. Bååth, "The use of phospholipid fatty acid analysis to estimate bacterial and fungal biomass in soil," Biol. Fertil. Soils. 22 (1-2), 59-65. 1996.

22. J. N. Galloway, F. J. Dentener, D. G. Capone, E. W. Boyer, R. W. Howarth, S. P. Seitzinger, and C. J. Vöos-marty, "Nitrogen cycles: past, present, and future," Biogeochemistry 70 (2), 153-226 (2004).

23. D. P. German, M. N. Weintraub, A. S. Grandy, C. L. Lauber, Z. L. Rinkes, and S. D. Allison, "Optimization of hydrolytic and oxidative enzyme methods for ecosystem studies," Soil Biol. Biochem. 43 (7), 1387-1397 (2011). 
24. G. W. Gooday, in Biochemistry of Microbial Degradation (Springer-Verlag, Dordrecht, 1994), pp. 279-312.

25. N. He, Q. Yu, R. Wang, Y. Zhang, Y. Gao, and G. Yu, "Enhancement of carbon sequestration in soil in the temperature grasslands of Northern China by addition of nitrogen and phosphorus," PloS One 8 (10), 10021004 (2013).

26. D. Hiltbrunner, S. Zimmermann, S. Karbin, F. Hagedorn, and P. A. Niklaus, "Increasing soil methane sink along a 120 -year afforestation chronosequence is driven by soil moisture," Global Change Biol. 18 (12), 36643671 (2012).

27. S. E. Hobbie, "Contrasting effects of substrate and fertilizer nitrogen on the early stages of litter decomposition," Ecosystems 8 (6), 644-656 (2005).

28. S. J. Horn, G. Vaaje-Kolstad, B. Westereng, and V. G. Eijsink, "Novel enzymes for the degradation of cellulose," Biotechnol. Biofuels 5 (1), 1-13 (2012).

29. S. Jagadamma and R. Lal, "Distribution of organic carbon in physical fractions of soils as affected by agricultural management," Biol. Fertil. Soils 46 (6), 543554 (2010).

30. J. D. Jastrow, J. E. Amonette, and V. L. Bailey, "Mechanisms controlling soil carbon turnover and their potential application for enhancing carbon sequestration," Clim. Change 80 (1-2), 5-23 (2007).

31. P. N. Kamble, J. Rousk, S. D. Frey, and E. Bååth, "Bacterial growth and growth-limiting nutrients following chronic nitrogen additions to a hardwood forest soil," Soil Biol. Biochem. 59 (2), 32-37 (2013).

32. L. Kang, X. Han, Z. Zhang, and O. J. Sun, "Grassland ecosystems in China: review of current knowledge and research advancement," Phil. R. Soc. B 362 (1482), 997-1008 (2007).

33. B. L. Keeler, S. E. Hobbie, and L. E. Kellogg, "Effects of long-term nitrogen addition on microbial enzyme activity in eight forested and grassland sites: implications for litter and soil organic matter decomposition," Ecosystems 12 (1), 1-15 (2009).

34. K. Y. Khan, A. I. Pozdnyakov, and B. K. Son, "Structure and stability of soil aggregates," Eurasian Soil Sci. 40 (4), 409-414 (2007).

35. J. Kohler, G. Tortosa, J. Cegarra, F. Caravaca, and A. Roldán, "Impact of DOM from composted "alperujo" on soil structure, AM fungi, microbial activity and growth of Medicago sativa," Waste Manage. 28 (8), 1423-1431 (2008).

36. A. Y. Kong, K. Hristova, K. M. Scow, and J. Six, "Impacts of different $\mathrm{N}$ management regimes on nitrifier and denitrifier communities and $\mathrm{N}$ cycling in soil microenvironments," Soil Biol. Biochem. 42 (9), 1523-1533 (2010).

37. A. Y. Kong, K. M. Scow, A. L. Córdova-Kreylos, W. E. Holmes, and J. Six, "Microbial community composition and carbon cycling within soil microenvironments of conventional, low-input, and organic cropping systems," Soil Biol. Biochem. 43 (1), 20-30 (2011).

38. A. Kulmatiski and K. H. Beard, "Long-term plant growth legacies overwhelm short-term plant growth effects on soil microbial community structure," Soil Biol. Biochem. 43 (4), 823-830 (2011).
39. D. S. LeBauer and K. K. Treseder, "Nitrogen limitation of net primary productivity in terrestrial ecosystems is globally distributed," Ecology. 89 (2), 371-379 (2008).

40. W. Liu, L. Jiang, S. Hu, L. Li, L. Liu, and S. Wan, "Decoupling of soil microbes and plants with increasing anthropogenic nitrogen inputs in a temperate steppe," Soil Biol. Biochem. 72 (6), 116-122 (2014).

41. X. Liu, L. Duan, J. Mo, E. Du, J. Shen, X. Lu, Y. Zhang, X. Zhou, C. He, and F. Zhang, "Nitrogen deposition and its ecological impact in China: an overview,” Environ. Pollut. 159 (10), 2251-2264 (2011).

42. X. Liu, Y. Zhang, W. Han, et al., "Enhanced nitrogen deposition over China," Nature 494 (7438), 459-462 (2013).

43. F. M. Lü, X. T. Lü, W. Liu, X. Han, G. M. Zhang, D. L. Kong, and X. G. Han, "Carbon and nitrogen storage in plant and soil as related to nitrogen and water amendment in a temperate steppe of northern China," Biol. Fertil. Soils 47 (2), 187-196 (2011).

44. S. Malherbe and T. E. Cloete, "Lignocellulose biodegradation: fundamentals and applications," Rev. Environ. Sci. Biotechnol. 1 (2), 105-114 (2002).

45. N. W. Mungai, P. P. Motavalli, R. J. Kremer, and K. A. Nelson, "Spatial variation of soil enzyme activities and microbial functional diversity in temperate alley cropping systems," Biol. Fertil. Soils 42 (2), 129136 (2005).

46. Olsen, S.R. Estimation of Available Phosphorus in Soils by Extraction with Sodium Bicarbonate (U.S. Department of Agriculture, Washington DC, 1954), pp. 1819.

47. J. Rousk, P. C. Brookes, and E. Bååth, "Fungal and bacterial growth responses to $\mathrm{N}$ fertilization and $\mathrm{pH}$ in the 150-year "Park Grass" UK grassland experiment," FEMS Microbiol. Ecol. 76 (1), 89-99 (2011).

48. K. R. Saiya-Cork, R. L. Sinsabaugh, and D. R. Zak, "The effects of long term nitrogen deposition on extracellular enzyme activity in an Acer saccharum forest soil," Soil Biol. Biochem. 34 (9), 1309-1315 (2002).

49. H. Sarula Chen, X. Hou, L. Ubugunov, O. Vishnyakova, X. Wu, et al., "Carbon storage under different grazing management in the typical steppe," Eurasian Soil Sci. 47 (11), 1152-1160 (2014).

50. V. M. Semenov, L. A. Ivannikova, T. V. Kuznetsova, N. A. Semenova, and A. S. Tulina, "Mineralization of organic matter and the carbon sequestration capacity of zonal soils," Eurasian Soil Sci. 41 (7), 717-730 (2008).

51. V. M. Semenov, L. A. Ivannikova, N. A. Semenova, A. K. Khodzhaeva, and S. N. Udal'tsov, "Organic matter mineralization in different soil aggregate fractions," Eurasian Soil Sci. 43 (2), 141-148 (2010).

52. A. Sessitsch, A. Weilharter, M. H. Gerzabek, H. Kirchmann, and E. Kandeler, "Microbial population structures in soil particle size fractions of a long-term fertilizer field experiment," Appl. Environ. Microbiol. 67 (9), 4215-4224 (2001).

53. R. C. Shen, M. Xu, Y. C. Gang, Y. Shen, and S. Q. Wan, "Soil microbial responses to experimental warming and nitrogen addition in a temperate steppe of northern China," Pedosphere 24 (4), 427-436 (2014). 
54. R. L. Sinsabaugh, M. M. Carreiro, and D. A. Repert, "Allocation of extracellular enzymatic activity in relation to litter composition, $\mathrm{N}$ deposition, and mass loss," Biogeochemistry 60 (1), 1-24 (2002).

55. J. Six, E. T. Elliott, and K. Paustian, "Soil macroaggregate turnover and microaggregate formation: a mechanism for C sequestration under no-tillage agriculture," Soil Biol. Biochem. 32 (14), 2099-2103 (2000).

56. R. Spaccini and A. Piccolo, "Effects of field managements for soil organic matter stabilization on water-stable aggregate distribution and aggregate stability in three agricultural soils," J. Geochem. Explor. 129 (6), 45-51 (2013).

57. R. Spaccini and A. Piccolo, in Carbon Sequestration in Agricultural Soils. A Multidisciplinary Approach to Innovative Methods (Springer-Verlag, Berlin, 2012), pp. 61105.

58. S. Steinbeiss, H. Beßler, C. Engels, et al., "Plant diversity positively affects short-term soil carbon storage in experimental grasslands," Global Change Biol. 14 (12), 2937-2949 (2008).

59. C. J. Stevens, N. B. Dise, J. O. Mountford, and D. J. Gowing, "Impact of nitrogen deposition on the species richness of grasslands," Science 303 (5665), 1876-1879 (2004).

60. M. Stursova, C. L. Crenshaw, and R. L. Sinsabaugh, "Microbial responses to long-term $\mathrm{N}$ deposition in a semiarid grassland," Microb. Ecol. 51 (1), 90-98 (2006).

61. M. Štursová, L. Žifčáková, M. B. Leigh, R. Burgess, and P. Baldrian, "Cellulose utilization in forest litter and soil: identification of bacterial and fungal decomposers," FEMS Microbiol. Ecol. 80 (3), 735-746 (2012).

62. K. N. Suding, S. L. Collins, L. Gough, et al., "Functional-and abundance-based mechanisms explain diversity loss due to N fertilization," Proc. Natl. Acad. Sci. U.S.A. 102 (12), 4387-4392 (2005).

63. K. K. Treseder, "Nitrogen additions and microbial biomass: a meta-analysis of ecosystem studies," Ecol. Lett. 11 (10), 1111-1120 (2008).

64. M. G. van Der Heijden, R. D. Bardgett, and N. M. van Straalen, "The unseen majority: soil microbes as drivers of plant diversity and productivity in terrestrial ecosystems," Ecol. Lett. 11 (3), 296-310 (2008).

65. M. P. Waldrop and D. R. Zak, "Response of oxidative enzyme activities to nitrogen deposition affects soil concentrations of dissolved organic carbon," Ecosystems 9 (6), 921-933 (2006).

66. M. P. Waldrop, D. R. Zak, R. L. Sinsabaugh, M. Gallo, and C. Lauber, "Nitrogen deposition modifies soil carbon storage through changes in microbial enzymatic activity," Ecol. Appl. 14 (4), 1172-1177 (2004).

67. R. Z. Wang, T. R. Filley, Z. W. Xu, X. Wang, M. H. Li, Y. G. Zhang, W. T. Luo, and Y. Jiang, "Coupled response of soil carbon and nitrogen pools and enzyme activities to nitrogen and water addition in a semi-arid grassland of Inner Mongolia,” Plant Soil 381 (1-2), 323-336 (2014).

68. C. Wei, H. Zheng, Q. Li, et al., "Nitrogen addition regulates soil nematode community composition through ammonium suppression," PloS One 7 (8), 1601-1620 (2012).

69. K. A. Whittinghill, W. S. Currie, D. R. Zak, A. J. Burton, and K. S. Pregitzer, "Anthropogenic N deposition increases soil C storage by decreasing the extent of litter decay: analysis of field observations with an ecosystem model," Ecosystems 15 (3), 450-461 (2012).

70. Z. W. Xu, S. Q. Wan, H. Y. Ren, X. G. Han, and Y. Jiang, "Influences of land use history and short-term nitrogen addition on community structure in temperate grasslands," J. Arid Environ. 87 (12), 103-109 (2012).

71. Z. Xu, S. Wan, G. Zhu, H. Ren, and X. Han, "The influence of historical land use and water availability on grassland restoration," Restor. Ecol. 18 (1), 217-225 (2010).

72. H. Yao, D. Bowman, T. Rufty, and W. Shi, "Interactions between $\mathrm{N}$ fertilization, grass clipping addition and $\mathrm{pH}$ in turf ecosystems: implications for soil enzyme activities and organic matter decomposition," Soil Biol. Biochem. 41 (7), 1425-1432 (2009).

73. Q. Yu, Q. Chen, J. Elser, et al., "Linking stoichiometric homoeostasis with ecosystem structure, functioning and stability," Ecol. Lett. 13 (11), 1390-1399 (2010).

74. Q. Yu, H. Wu, N. He, et al., "Testing the growth rate hypothesis in vascular plants with above-and belowground biomass," PloS One 7 (3), e32162 (2012).

75. E. S. Zavaleta, M. R. Shaw, N. R. Chiariello, B. D. Thomas, E. E. Cleland, C. B. Field, and H. A. Mooney, "Grassland responses to three years of elevated temperature, $\mathrm{CO}_{2}$, precipitation, and $\mathrm{N}$ deposition," Ecol. Monogr. 73 (4), 585-604 (2003).

76. L. H. Zeglin, M. Stursova, R. L. Sinsabaugh, and S. L. Collins, "Microbial responses to nitrogen addition in three contrasting grassland ecosystems," Oecologia 154 (2), 349-359 (2007).

77. L. Zelles, "Phospholipid fatty acid profiles in selected members of soil microbial communities," Chemosphere 35 (1-2), 275-294 (1997).

78. N. Zhang, W. Xu, X. Yu, D. Lin, S. Wan, and K. Ma, "Impact of topography, annual burning, and nitrogen addition on soil microbial communities in a semiarid grassland," Soil Sci. Soc. Am. J. 77 (4), 1214-1224 (2013).

79. X. Zhou, C. Chen, Y. Wang, Z. Xu, H. Han, L. Li, and S. Wan, "Warming and increased precipitation have differential effects on soil extracellular enzyme activities in a temperate grassland," Sci. Total Environ. 444 (2), 552-558 (2013).

80. C. Ziter and A. S. MacDougall, "Nutrients and defoliation increase soil carbon inputs in grassland," Ecology 94 (1), 106-116 (2013). 